\title{
Difference in localization of eosinophils and mast cells in the bovine ovary
}

\author{
I. Reibiger and K. Spanel-Borowski \\ Department of Anatomy, University of Leipzig, Liebigstrasse 13, D-04103 Leipzig, Germany
}

\begin{abstract}
The bovine ovary contains a considerable number of leucocytes which can be located with an antibody against the CD18 molecule. In the present study, subtyping and cell counting were carried out on histological sections stained with Sirius red for eosinophils and with toluidine blue for mast cells. The $\mathrm{CD} 18^{+}$cells were identified immunohistologically. Eosinophils and mast cells contributed considerably to the $\mathrm{CD} 18^{+}$pool. The number of eosinophils in the corpus luteum increased rapidly in early development to approximately $90 \%$ of the $\mathrm{CD}^{+} 8^{+}$cells, and decreased to $30 \%$ during secretion and to $10 \%$ during regression. Mast cells were not detectable in the follicles, the corpus luteum and the periphery of the cortex, but were observed in the interstitial cortical stroma and the medulla. The number of mast cells in these regions, which corresponded to $60-76 \%$ of the $\mathrm{CD} 18^{+}$cells, did not change significantly throughout the oestrous cycle. It is concluded that eosinophils are selectively recruited at the periovulatory period and that mast cells are unevenly distributed.
\end{abstract}

\section{Introduction}

Leucocytes invade specific regions of the mammalian ovary at precise times of the oestrous cycle and may be involved in regulating the life cycle of follicles and corpora lutea (Pate, 1995; Vinatier et al., 1995; Norman and Brännström, 1996). Preferentially segmented leucocytes are observed in preovulatory follicles. In rats and humans, these cells are identified as neutrophils by immunohistology (Brännström et al., 1993, 1994a,b; Best et al., 1996), whereas in sheep and pigs, eosinophils have been observed in Giemsa-stained sections and electron microscopy (Cavender and Murdoch, 1988; Murdoch and Steadman, 1991; Standaert et al., 1991). In cows, the presence of eosinophils in preovulatory follicles was described 40 years ago (Cupps et al., 1959).

Eosinophils are known to be involved in parasitic infestation, asthma and allergic conditions (Bignold, 1995). The physiological significance of these cells is still unclear. Eosinophils are an important source of numerous growth factors, cytokines and chemokines associated with crystalloid secretory granules (Walsh, 1997). They are rapidly mobilized and may release inflammatory mediators that control leucocyte recruitment, degradation of the basal membrane and angiogenesis. Since these events play a role during follicular rupture, ovulation has been described as a 'physiological inflammation', and eosinophils are considered to contribute to the inflammatory nature of this event (Espey, 1994). Eosinophils are also thought to participate in luteolysis due to their occurrence in regressing corpora lutea

Revised manuscript received 25 October 1999 of pigs (Standaert et al, 1991) and of sheep after treatment with PGF $_{2 \alpha}$ (Murdoch, 1987; Murdoch et al., 1988). If this is the case, eosinophils should be detected in regressing corpora lutea of cows, a species with a long oestrous cycle which is comparable to that in pigs and sheep; such a study has not been carried out.

Mast cells are widely distributed throughout many different tissues and organs and have been located in the ovaries of mice, rats, hamsters and cows (Jones et al., 1980; Nakamura et al., 1987; Krishna et al., 1989; Krishna and Jaiswal, 1994). In species with a well developed interstitial cortical stroma and a long oestrous cycle such as cows, mast cells reside in the cortex and in the medulla (Nakamura et al., 1987). In species with a short oestrous cycle, such as rats and hamsters, mast cells are found only in the medulla (Jones et al., 1980; Krishna et al., 1989). Mast cells appear to degranulate and to release histamine under the influence of the LH peak as described for hamsters (Krishna and Terranova, 1985). Similar to eosinophils, mast cells produce a number of inflammatory mediators which are composed and activated in such way that leucocytes are recruited (Kubes and Granger, 1996; McNeil, 1996). In view of the similar functions in leucocyte recruitment, the location of both eosinophils and mast cells in the bovine ovary is worthy of investigation.

In the bovine ovary, the accumulation and number of leucocytes depends upon the type of follicle and the different stages of the corpora lutea, as shown by immunolocalization of CD18 $8^{+}$cells (Spanel-Borowski et al., 1997). The distribution of eosinophils and mast cells has not been studied in depth. Therefore, the aim of this study was to investigate leucocyte subtypes in the bovine ovary. 


\section{Materials and Methods}

A total of 45 pairs of bovine ovaries were collected at a local abattoir immediately after the animals were killed and the ovaries were transported to the laboratory in $0.05 \mathrm{~mol} \mathrm{PBS} \mathrm{l}^{-1}$. The ovaries were classified into the different stages of the oestrous cycle from appearance with the naked eye (Ireland et al., 1980) and by histological and biochemical findings (Ricken et al., 1995). At the follicular stage, ovaries $(n=6)$ contained dominant follicles between 1 and $2 \mathrm{~cm}$ in diameter and showed regressive corpora lutea of the preceding oestrous cycle. This was considered to indicate that the selected ovaries were from cyclic cows. The follicular wall of the dominant follicles consisted of folds, as verified subsequently by histology. During early development $(n=6)$, the corpus luteum was red and up to $0.5 \mathrm{~mm}$ in diameter. Owing to convolutions of the luteinizing thecal layer, prominent septa were found. During the stage of late development $(n=6)$, the capillary bed (detected by a factor VIIIr positive immunoresponse as reported by Ricken et al. (1995)), was seen clearly. In the early secretory stage of $(n=7)$, simple connective tissue septa were observed in the corpora lutea and the capillary bed was at the highest density. A decrease in the density of the capillaries was apparent in the late secretory stage $(n=7)$. The absence of capillaries and the presence of arterioles were typical during regression (early stage $n=7$; late stage $n=6$ ).

\section{Fixation and staining}

The ovaries were cut into three pieces containing either antral follicles or corpora lutea and each with a portion of the interstitial cortical stroma and the medulla. One piece was fixed in liquid nitrogen and stored at $-20^{\circ} \mathrm{C}$ until required. The other two pieces were fixed in $4 \%(\mathrm{v} / \mathrm{v})$ buffered formaldehyde with or without $5 \%(\mathrm{w} / \mathrm{v})$ lead acetate for approximately $12 \mathrm{~h}$ and embedded in paraffin wax. Sections $(7 \mu \mathrm{m})$ were mounted on slides precoated with the paper glue (Cementit ${ }^{\circledR}$; Merz and Benteli AG, Niederwangen). The eosinophils were stained specifically in the formaldehydefixed tissue as reported by Bogomoletz (1980). Sirius red (500 mg; Bayer AB, Leverkusen) was dissolved in $45 \mathrm{ml}$ aqua bidest, $50 \mathrm{ml}$ absolute ethanol and $1 \mathrm{ml}$ of $1 \%(\mathrm{w} / \mathrm{v}) \mathrm{NaOH}$, and approximately $4 \mathrm{ml}$ of $20 \%(\mathrm{w} / \mathrm{v}) \mathrm{NaCl}$ was added until slight precipitation had occurred. The solution was filtered on the following day and kept stable for 2 months at room temperature. Paraffin wax was removed from the sections and they were stained with haematoxylin, differentiated in running tap water, treated with $70 \%$ ethanol and stained with Sirius red solution at room temperature for $1 \mathrm{~h}$. After complete dehydration with increasing concentrations of ethanol, the sections were mounted in Canada balsam. Mast cells were detected in tissues fixed in $4 \%(\mathrm{v} / \mathrm{v})$ buffered formaldehyde together with $5 \%(\mathrm{w} / \mathrm{v})$ lead acetate. The cells were stained with $1 \%(\mathrm{w} / \mathrm{v})$ toluidine solution for $20 \mathrm{~min}$, dehydrated and mounted as described earlier.

\section{Indirect immunohistology}

Integrins of the $\beta_{2}$ type are known to be expressed selectively by mononuclear and segmented leucocytes (Bosman, 1993). Type $\beta_{2}$ integrins were detected in $10 \mu \mathrm{m}$ cryostat sections using a monoclonal antibody against the CD18 chain of bovine $\beta_{2}$ integrins (VMRD, Inc., Pullman, WA). The avidin-biotin-horseradish peroxidase (HRP) complex technique was used (Vectostain ${ }^{\circledR}$ Elite ABC kit from Vector Laboratories, supplied by Alexis, Grünberg) and 0.05 mol PBS $\mathrm{l}^{-1}$ and $0.05 \mathrm{~mol}$ Tris-buffered saline $\mathrm{l}^{-1}$ (TBS, $\mathrm{pH}$ 7.6) for antibody dilution and buffer rinses. The rinses were carried out between steps (2) and (4), using TBS with $0.125 \%(\mathrm{v} / \mathrm{v})$ Tween (Biorad, Munich; $2 \times 5 \mathrm{~min}$ ) followed by TBS without Tween. (1) The slides were placed in a cuvette containing $0.3 \%(\mathrm{v} / \mathrm{v}) \mathrm{H}_{2} \mathrm{O}_{2}$ in absolute methanol for $30 \mathrm{~min}$ to eliminate endogenous peroxidase activity and to reduce the background staining. The slides were rinsed in TBS $(3 \times 5 \mathrm{~min})$ and treated with $2 \%$ normal goat serum for $30 \mathrm{~min}$. (2) Without a buffer rinse, the slides were incubated with the primary antibody diluted 1:100 in PBS with $0.25 \%$ bovine serum albumin (A-4378, Sigma, Deisenhofen). Incubation was continued overnight in a humidified chamber at $4^{\circ} \mathrm{C}$. The controls were run with an non-specific mouse immunoglobulin of the IgG1 subtype (DAKO, Hambourg), that is, the same subtype and protein concentration used for the primary antibody. (3) The slides were placed in a cuvette containing the second goat anti-mouse antibody (BA-9200, Vector Laboratories) diluted 1:200 in TBS with 1.5\% normal goat serum for $20 \mathrm{~min}$ at room temperature. (4) The sections were incubated with the avidin-biotin-HRP complex (40 drops of the kit solution in $50 \mathrm{ml} \mathrm{TBS}$ ) for $30 \mathrm{~min}$. (5) 3Amino-9-ethylcarbazole (29 mg; AEC, Sigma) was dissolved in $100 \mathrm{ml}$ of $0.1 \mathrm{~mol}$ sodium acetate buffer $\mathrm{l}^{-1}$ at $\mathrm{pH} 5.2$ and supplemented with $0.03 \%(\mathrm{v} / \mathrm{v}) \mathrm{H}_{2} \mathrm{O}_{2}$ and $7.1 \mathrm{ml} \mathrm{N}, N$ dimethylformamide (Sigma). The sections were treated with the AEC solution for $10 \mathrm{~min}$ at $37^{\circ} \mathrm{C}$. (6) After rinsing with distilled water and counterstaining with Ehrlich's haematoxylin, the sections were embedded in a water-soluble medium (Crystal Mount ${ }^{\circledR}$, Natutec GmbH, Frankfurt).

\section{Leucocyte counting}

An observer examined the same section on two occasions with an interval of 1 day. Since no significant differences in the number of $\mathrm{CD}_{18}{ }^{+}$cells were found, the number of eosinophils, mast cells and CD18 ${ }^{+}$leucocytes in the stained sections was determined once. In the dominant follicles, the layers of granulosa or theca cells were considered separately. In the developing corpora lutea, areas with luteinizing theca and granulosa cells were screened, whereas in subsequent stages, septa and luteal cells were considered. Within the interstitial cortical stroma and the medulla, the number of leucocytes in ten areas, each of $0.06 \mathrm{~mm}^{2}$, was counted, using the KS 100 Version 2.00 image analysis system (Kontron Elektronik, Eching, Munich). The mean values \pm SEM were calculated for samples at each stage of the oestrous cycle as well as percentages of eosinophils and mast cells in respect of the total number of CD18 ${ }^{+}$leucocytes. Statistically significant differences among all group means were assessed by the non-parametric Kruskal-Wallis-test, followed by the Mann-Whitney U test. 


\section{Results}

Eosinophils with a bilobed nucleus and distinct red staining of the cytoplasm were only observed in the dominant follicles and corpora lutea. Compared with antral follicles with negligible numbers of eosinophils, the dominant follicles contained some eosinophils that had spread irregularly throughout the theca. After follicular rupture, that is at the early developmental stage of the corpus luteum, there was a greater increase in the number of eosinophils in the theca than in the granulosa layer (Fig. 1a,b). A large number of eosinophils had accumulated within and around dilated vessels. At the late stage of development, the number of eosinophils remained greater in the luteinizing theca layer than in the granulosa layer, although the overall number was less than at the early stage. By the secretory stage, the corpus luteum had developed to its final size, and it was not possible to determine whether the large and small luteal cells were of granulosa or thecal origin. The number of eosinophils was small (Fig. 1c) and remained small during regression. The number of eosinophils decreased, while the number of $\mathrm{CD}_{18}{ }^{+}$cells increased (Fig. 1c,d). There was a peak in the number of eosinophils in the early stage of the developing corpus luteum, which was statistically different from the numbers observed in the subsequent stages (Fig. 2).

Unlike eosinophils, mast cells were never found in the walls of intact antral or dominant follicles (Fig. 3a). Mast cells did not invade the hypertrophied thecal layer or the fibrotic body of regressed antral follicles (Fig. 3b), nor did they invade new or old corpora lutea. Mast cells were not observed in completely regressed corpora lutea, as detected by arterioles with a thick media. Mast cells were rarely seen in the marginal zone of the interstitial cortical stroma, in which the primordial follicles were located (Fig. 3c). Mast cells appeared to be evenly spread in the major portion of the interstitial cortical stroma and were found in the vicinity of
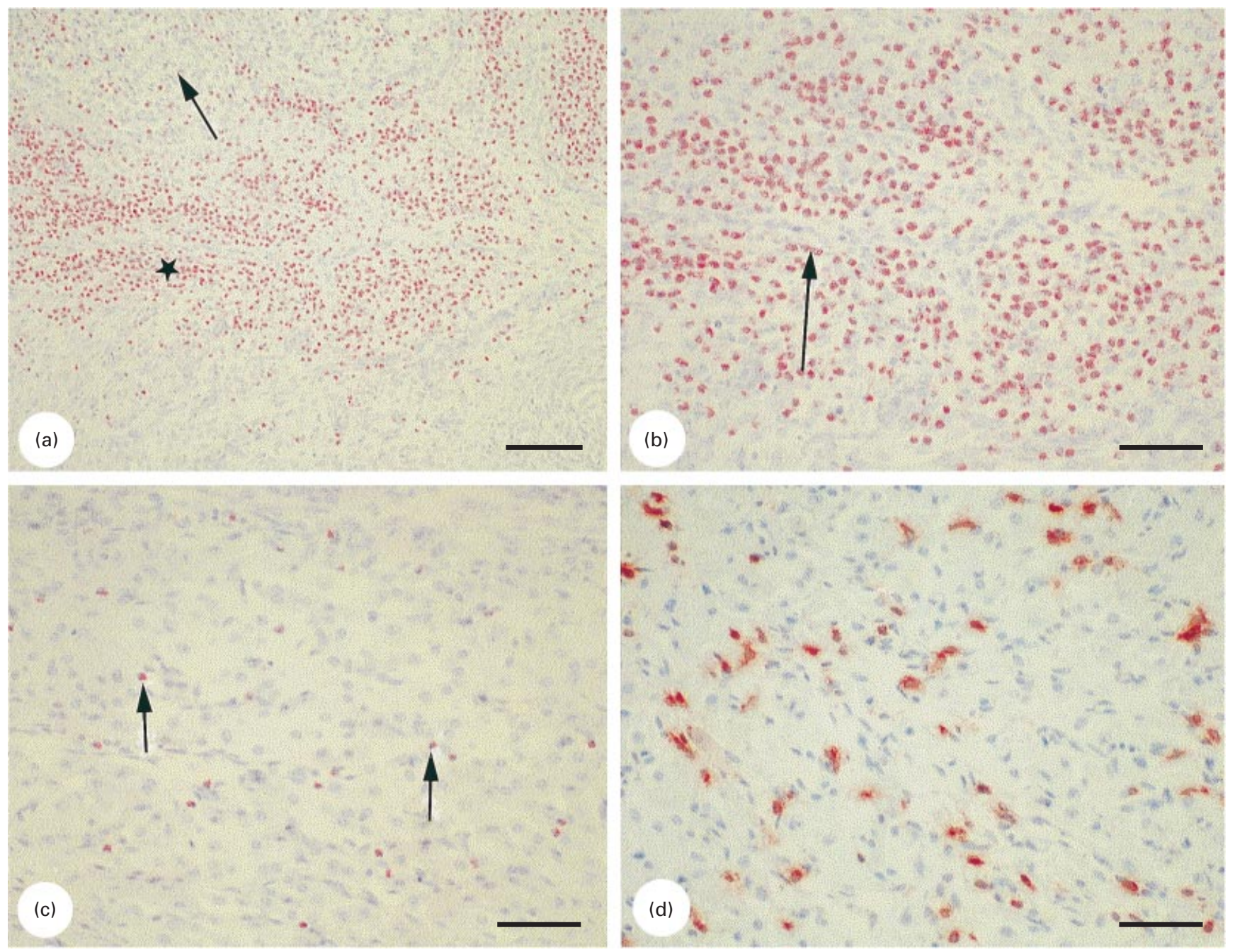

Fig. 1. Eosinophils in the bovine corpus luteum. (a) During early development, numerous eosinophils were observed in the former thecal layer $(*)$, whereas there were fewer eosinophils between the granulosa cells during luteinization (arrow). (b) Eosinophils were associated with postcapillary venules (arrow). (c) During the secretory stage, eosinophils (arrows) were sparsely distributed and fewer in number than CD18 leucocytes (d). (a-c) Sirius red staining; (d) indirect immunohistology. Scale bars represent (a) $100 \mu \mathrm{m}$ and (b-d) $50 \mu \mathrm{m}$. 
Table 1. Absolute number of CD18 cells in $0.6 \mathrm{~mm}^{2}$ areas of cortex and medulla and of dominant follicles and corpora lutea in the bovine ovary during different stages of the oestrous cycle

\begin{tabular}{|c|c|c|c|c|c|c|c|}
\hline \multirow[b]{3}{*}{ Compartment } & \multirow{3}{*}{$\begin{array}{c}\text { Follicular } \\
\text { stage } \\
n=6\end{array}$} & \multicolumn{6}{|c|}{ Stage of the corpus luteum } \\
\hline & & \multicolumn{2}{|c|}{ Development } & \multicolumn{2}{|c|}{ Secretion } & \multicolumn{2}{|c|}{ Regression } \\
\hline & & $\begin{array}{c}\text { Early } \\
n=6\end{array}$ & $\begin{array}{l}\text { Late } \\
n=6\end{array}$ & $\begin{array}{l}\text { Early } \\
n=7\end{array}$ & $\begin{array}{l}\text { Late } \\
n=7\end{array}$ & $\begin{array}{c}\text { Early } \\
n=7\end{array}$ & $\begin{array}{l}\text { Late } \\
n=6\end{array}$ \\
\hline \multicolumn{8}{|l|}{ Stroma } \\
\hline Cortex & $99 \pm 5$ & $164 \pm 21$ & $162 \pm 24$ & $114 \pm 25$ & $174 \pm 22$ & $163 \pm 18$ & $147 \pm 16$ \\
\hline Medulla & $170 \pm 16$ & $239 \pm 30$ & $202 \pm 25$ & $140 \pm 24$ & $238 \pm 13$ & $245 \pm 23$ & $236 \pm 30$ \\
\hline \multicolumn{8}{|l|}{ Follicle/corpus luteum } \\
\hline Granulosa/luteal cells & 0 & $145 \pm 21$ & $164 \pm 23$ & $100 \pm 8$ & $130 \pm 9$ & $189 \pm 32$ & Crowded \\
\hline Theca/luteal cells & $73 \pm 26$ & $335 \pm 47$ & $184 \pm 19$ & $106 \pm 10$ & $136 \pm 23$ & $205 \pm 24$ & Crowded \\
\hline
\end{tabular}

Values are means \pm SEM.

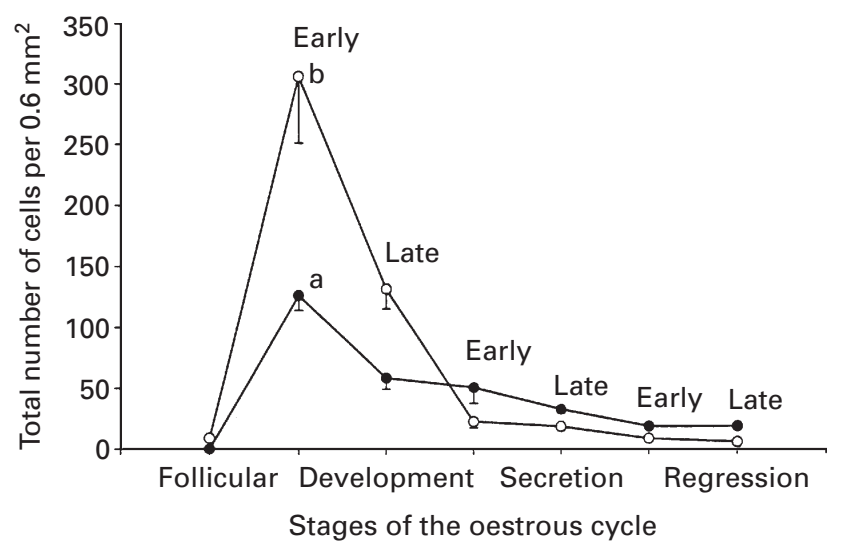

Fig. 2. The number of eosinophils in the bovine corpus luteum increased during early development. Histological sections were stained with Sirius red and cells were counted by examining dominant follicles during the follicular phase and corpora lutea at different stages. Values are mean \pm SEM. The numbers of eosinophils in the luteinizing granulosa layer $(\bullet)$ and the thecal layer $(O)$ were significantly different up to the secretory stage $(P<0.01$ to 0.05$)$. ${ }^{a} P<0.05$ and ${ }^{b} P<0.005$ versus late development.

the theca externa of antral and dominant follicles. A large number of mast cells were also observed in the medulla, often aligned within the adventitia of the shunt-like arteries (Fig. 3d). A considerable number of these mast cells were CD $18^{+}$cells as revealed by comparing sections stained for mast cells with those stained for all leucocytes (Fig. 3e,f). When the absolute number of mast cells was counted within the cortex or the medulla, a greater number of mast cells were found in the medulla than in the cortex. No obvious difference was detected among the different stages of the oestrous cycle, although there appeared to be smaller numbers of mast cells during the late developmental and secretory stages than during regression (Fig. 4).

The CD18+ leucocytes were observed in the same regions as the eosinophils and mast cells. They were also observed in other regions such as regressing or regressed antral follicles, and in old corpora lutea of different generations (data not shown). In the cortex and the medulla, the number of CD18+ cells appeared to remain constant throughout the oestrous cycle (Table 1). In the corpus luteum during early development and during regression, the number of $\mathrm{CD} 18^{+}$ positive cells showed peak values. This difference was statistically significant in the region of the theca/luteal cells during early development $(P<0.005)$ compared with the other stages. CD18 ${ }^{+}$leucocytes were present in very small numbers in the granulosa layer at the follicular stage; the number was significantly different compared with the other stages.

In comparison with the CD18+ cells, the percentage of eosinophils changed markedly: $90 \%$ during early development, $54 \%$ during late development, approximately $30 \%$ during the secretory stage, and $10 \%$ during regression. The less marked changes in the number of $\mathrm{CD}_{1} 8^{+}$cells (Table 1 ) indicate the influx of another leucocyte subtype during the later stages. The percentage of mast cells in relation to CD18 ${ }^{+}$ cells did not change significantly either in the cortex or the medulla. The percentage remained high throughout the oestrous cycle: $64 \%, 76 \%$ and $60 \%$ during development, secretion and regression, respectively. Hence, a considerable proportion of the CD18 ${ }^{+}$cells in the cortex and in the medulla represented mast cells.

\section{Discussion}

Eosinophils, mast cells and $\mathrm{CD}_{1} 8^{+}$cells were located in specific regions of the bovine ovary and the numbers of these cells at different stages of the oestrous cycle were determined. Simultaneous labelling of eosinophils or mast cells together with $\mathrm{CD} 18^{+}$cells was not possible with paraffin wax sections, which are excellent for staining eosinophils and mast cells, but inadequate for the immunohistological location of $\mathrm{CD} 18^{+}$cells. Simultaneous labelling of toluidine blue-stained mast cells and nerves has been achieved successfully with cryostat sections of the rat synovium after fixation with Bouin's solution (Hukkanen et al., 1991). In the 

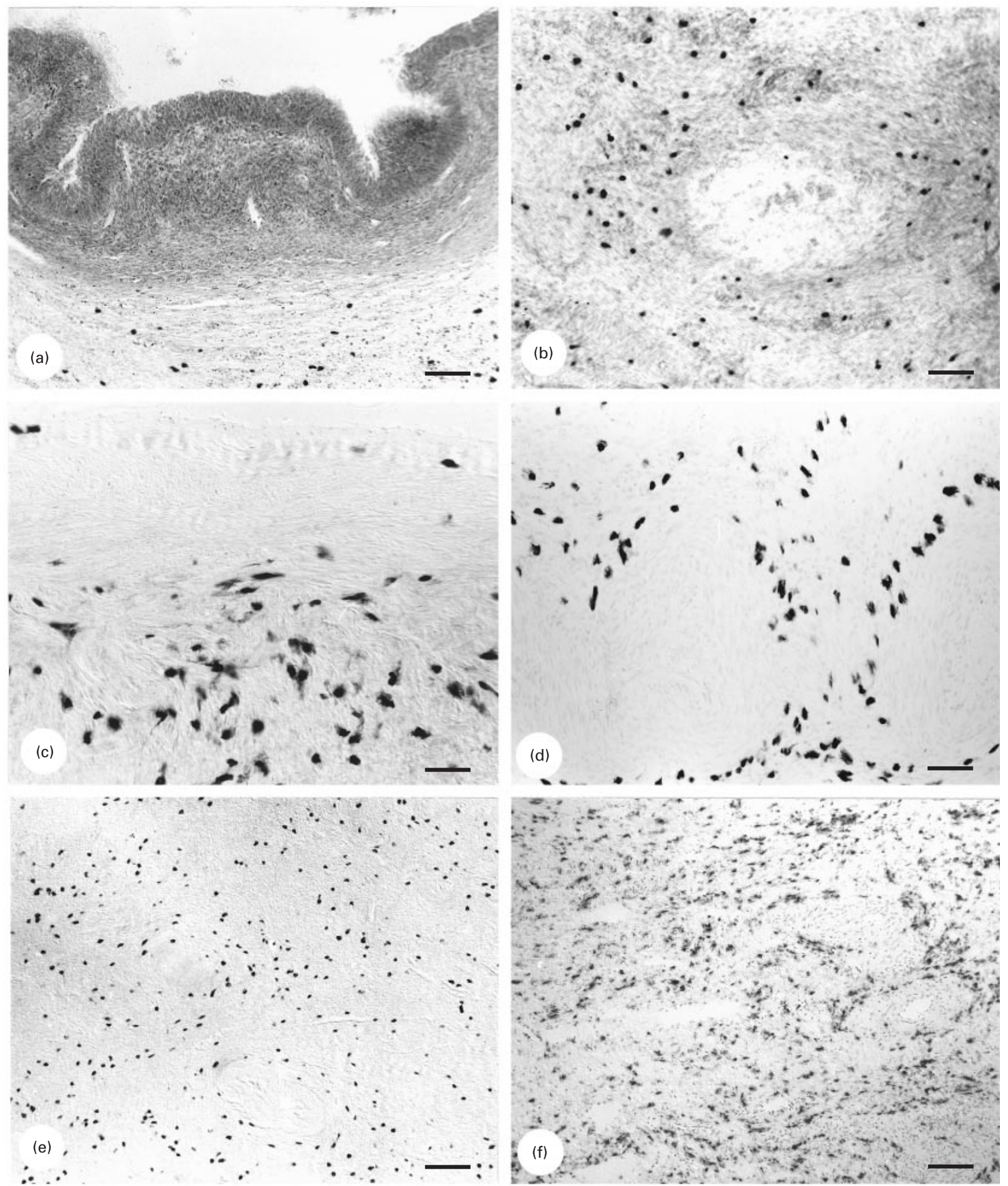

Fig. 3. Mast cells in the bovine ovary. The mast cells are observed in the interstitial cortical stroma and close to the wall of (a) a dominant follicle with a granulosal layer thrown into folds and (b) a fibrotic body which represents the final stage of follicular atresia. (c) Mast cells were not detected in the periphery of the cortex, but were present in large numbers in the adjoining interstitial cortical stroma. (d) In the medulla, mast cells are aligned within the adventitia of the muscular blood vessels with a thick media. (e) Mast cells are distributed throughout the medulla. (f) Many $\mathrm{CD}_{18}{ }^{+}$cells represent mast cells, as is apparent by comparing (e) with (f). (a-e) Toluidine blue staining; (f) indirect immunohistology. Scale bars represent (a,b,e and f) $100 \mu \mathrm{m}$ and (c,d) $50 \mu \mathrm{m}$. 


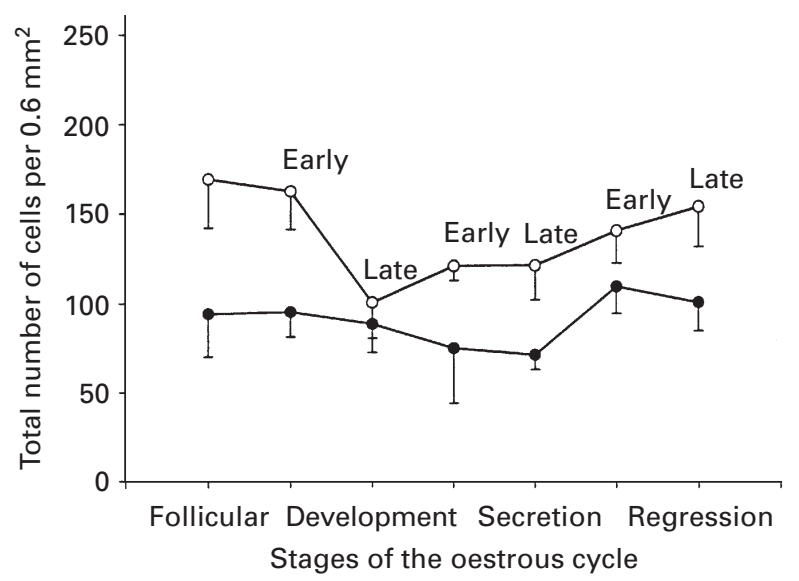

Fig. 4. The number of mast cells is greater in the medulla $(\bigcirc)$ than in the interstitial cortical stroma $(\bullet)$ of the bovine ovary. Histological sections were stained with toluidine blue and cells were counted at the follicular phase, and at the subsequent luteal stages. Values are mean \pm SEM.

present study, this procedure presented difficulties in discerning toluidine blue stained mast cells in the $\mathrm{CD} 18^{+}$cell pool due to overlapping responses. The problem was not resolved with the double-labelling technique against CD18 and against chymase or tryptase, which are mast cell-specific enzymes. The antibody, only available against the human chymase, showed no crossreactivity in the bovine ovary, whereas the antibody against the human tryptase detected just two-thirds of the mast cells stained with toluidine blue. Therefore, formaldehyde fixed cryostat sections were used, which were cut into series and stained consecutively with (i) toluidine blue, (ii) against the CD18 molecule and (iii) with Sirius red. The outcome supported the results obtained with paraffin wax sections: the major portion of $\mathrm{CD} 18^{+}$cells in the medulla and the interstitial cortical stroma represented mast cells.

A small number of eosinophils were observed in the theca of antral and dominant follicles in contrast to other studies of preovulatory follicles of sheep and pigs (Cavender and Murdoch, 1988; Standaert et al., 1991). These studies failed to detect a sudden increase in the number of eosinophils in the developing corpus luteum. This finding is in contrast to those of the present study in which the time-frame for the selective influx of eosinophils was restricted to only 1 or 2 days. The mechanism appears to be under the control of specific adhesion molecules such as very late activation antigen 4 (VLA-4), a $\beta_{1}$ integrin expressed on eosinophils, and the vascular cell adhesion molecule (VCAM-1), a member of the immunoglobulin superfamily that is upregulated on endothelial cells (Wardlaw et al., 1994; Bochner and Schleimer, 1994). In additional, interleukin 3 and 5 promote the adhesion of eosinophils to microvascular endothelial cells (Walsh et al., 1991) as well as RANTES (regulated on activation, normal T-cell expressed and secreted) and eotaxin, chemoattractants of the C-Cchemokine family (Okada et al., 1997; Walsh, 1997). Experiments on RANTES and eotaxin expression in the bovine ovary are being carried out with RT-PCR and in situ hybridization. The preliminary results indicate that ovarian macrophages are involved in the precisely timed recruitment of eosinophils (Aust et al., 1999).

The signal for the recruitment of eosinophils and other leucocytes is probably related to the LH peak, inducing granulosa cells to suddenly release inflammatory mediators (Norman and Brännström, 1996). Slight alterations in the amount and composition of the mediators may be responsible for the variation in the number of eosinophils observed among the samples in the present study. The occurrence of eosinophils runs in parallel with the period of angiogenesis and luteinization, supporting the proposal that eosinophils may influence both events (Murdoch and Steadman, 1991). During the secretory stage, a small number of eosinophils was observed throughout the corpus luteum, which probably reflects cessation in the mechanism for recruiting eosinophils together with an increase in the size of the fully grown corpus luteum. A second eosinophil influx in the bovine corpus luteum at the onset of luteolysis was not observed in the present study, which is in contrast to reports for sheep and pigs (Cavender and Murdoch, 1988; Murdoch and Steadman, 1991; Standaert et al., 1991). This discrepancy may be explained by species differences or differences in fixation, staining, and in pretreatment with or without prostaglandin.

In the present study, mast cells were not detected on the inside of the follicles and corpora lutea, and were present in high density in the medulla and the interstitial cortical stroma throughout the oestrous cycle. This uneven distribution was also observed in human ovaries (U. Heider and K. SpanelBorowski, unpublished). Nakamura et al. (1987) counted these cells in the theca externa of dominant follicles and in the capsule of corpora lutea and did not observe mast cells in the interstitial cortical stroma of the bovine ovary. However, the theca externa of a dominant follicle consists of a few cell layers in a circular arrangement around the basal membrane in the absence of a distinct border towards the cortical stroma. Therefore, the theca externa may be confused with the cortical stroma. The capsule of a corpus luteum represents the interstitial cortical stroma because of the complete transition of the theca into the corpus luteum.

The function of intraovarian mast cells requires clarification. Currently, they are thought to be involved in the increased vascular permeability after degranulation and histamine release during the preovulatory period (Jones et al., 1980; Krishna et al., 1989). Degranulation is reflected by a decrease in mast cells in the bovine cortex surrounding the developing corpus luteum (Nakamura et al., 1987). In the present study, a decrease in the number of mast cells was observed during the late stage of corpus luteum development, which was not statistically significant due to the limited amount of material at this stage. Mast cells tended to accumulate in the bovine ovary within the adventitia of thick muscular arteries, indicating that these cells may be influential in smooth muscle tone. It is known that mast cells form synaptic-like contacts with nerve fibres in the skin and gastrointestinal tract (McKay and Bienenstock, 1994, Botchkarev et al., 1997). If these contacts are present in the ovary, membrane depolarization at the synaptic-like 
contact is followed by release of cytokines and neuropeptides from mast cells. Their factors are able to bind to corresponding receptors of nerve fibres. Hence, mast cells, together with nerve fibres, may form a bidirectional interaction and be responsible for the local neuroimmune connection. Mediators of mast cells act on endothelial cells and eosinophils in the recruitment of eosinophils (Kubes and Granger 1996; Oskéritzian et al., 1996). It is apparent from these observations that the intraovarian relationships among eosinophils, mast cells and nerves require further investigation.

The authors thank the Interdisciplinary Center of Clinical Research (IZKF) at the University of Leipzig for supporting this project B6 financially. They also thank F. Steel, Freiburg, Germany, for his help with English grammar and style.

\section{References}

Aust G, Brylla E, Lehmann I, Kiessling S and Spanel-Borowski K (1999) Cloning of bovine RANTES mRNA and its expression and regulation in ovaries in the periovulatory period FEBS Letters 463 160-164

Best CL, Pudney J, Welch WR, Burger N and Hill JA (1996) Localization and characterization of white blood cell populations within the human ovary throughout the menstrual cycle and menopause Human Reproduction $\mathbf{1 1}$ 790-797

Bignold LP (1995) The eosinophil leukocyte: controversies of recruitment and function Experientia 51 317-327

Bochner BS and Schleimer RP (1994) The role of adhesion molecules in human eosinophil and basophil recruitment Journal of Allergy and Clinical Immunology 94 427-438

Bogomoletz W (1980) Avantages de la coloration par le rouge sirius de l'amyloïde et des eosinophiles Archives d'Anatomie et de Cytologie Pathologiques 28 252-253

Bosman FT (1993) Integrins: cell adhesives and modulators of cell function Histochemical Journal 5 469-477

Botchkarev VA, Eichmüller S, Peters EMJ, Pietsch P, Johansson O, Maurer M and Paus R (1997) A simple immunofluorescence technique for simultaneous visualization of mast cells and nerve fibers reveals selectivity and hair cycle-dependent changes in mast cell-nerve fiber contacts in murine skin Archives of Dermatological Research 289 292-302

Brännström M, Mayerhofer G and Robertson SA (1993) Localization of leukocyte subsets in the rat ovary at the periovulatory period Biology of Reproduction 48 277-286

Brännström M, Giesecke L, Moore IC, van den Heuvel CJ and Robertson SA (1994a) Leukocyte subpopulations in the rat corpus luteum at pregnancy and pseudopregnancy Biology of Reproduction 50 1161-1167

Brännström M, Pascoe V, Norman RJ and McClure N (1994b) Localization of leukocyte subsets in the follicle wall and in the corpus luteum throughout the human menstrual cycle Fertility and Sterility 61 488-495

Cavender JL and Murdoch WJ (1988) Morphological studies of the microcirculatory system of periovulatory ovine follicles Biology of Reproduction 39 989-997

Cupps PT, Laben RC and Mead SW (1959) Histology of pituitary, adrenal, and reproductive organs in normal cattle and cattle with lowered reproductive efficiency Hilgardia 29 383-410

Espey LL (1994) Current status of the hypothesis that mammalian ovulation is comparable to an inflammatory reaction Biology of Reproduction 50 233-238

Hukkanen M, Grönblad M, Rees R, Konttinen YT, Gibson SJ, Hietanen J, Polak JM and Brewerton DA (1991) Regional distribution of mast cells and peptide containing nerves in normal and adjuvant arthritic rat synovium Journal of Rheumatology 18 177-183
Ireland JJ, Murphee RL and Coulson PB (1980) Accuracy of predicting stages of bovine estrous cycle by gross appearance of the corpus luteum Journal of Dairy Science 63 155-160

Jones RE, Duvall D and Guillette LJ, Jr (1980) Rat ovarian mast cells: distribution and cyclic changes Anatomical Record 197 489-493

Krishna A and Jaiswal K (1994) Changes in the mast cell number and degranulation pattern during periovulatory period and after blocking gonadotrophin surge in mice ovarian compartments Acta Physiologica Hungarica 82 415-421

Krishna A and Terranova PF (1985) Alterations in mast cell degranulation and ovarian histamine in the proestrus hamster Biology of Reproduction 32 1211-1217

Krishna A, Beesley K and Terranova PF (1989) Histamine, mast cells and ovarian function Journal of Endocrinology 120 363-371

Kubes P and Granger DN (1996) Leukocyte-endothelial cell interactions evoked by mast cells Cardiovascular Research 32 699-708

McKay DM and Bienenstock J (1994) The interaction between mast cells and nerves in the gastrointestinal tract Immunology Today 15 533-538

McNeil HP (1996) The mast cell and inflammation Australian and New Zealand Journal of Medicine 26 216-225

Murdoch WJ (1987) Treatment of sheep with prostaglandin F2 $\alpha$ enhances production of a luteal chemoattractant for eosinophils American Journal of Reproductive Immunology and Microbiology 15 52-56

Murdoch WJ and Steadman LE (1991) Investigations concerning the relationship of ovarian eosinophilia to ovulation and luteal function in the sheep American Journal of Reproductive Immunology 25 81-87

Murdoch WJ, Steadman LE and Belden EL (1988) Immunoregulation of luteolysis Medical Hypotheses 27 197-199

Nakamura Y, Smith M, Krishna A and Terranova PF (1987) Increased number of mast cells in the dominant follicle of the cow: relationships among luteal, stromal, and hilar regions Biology of Reproduction 37 546-549

Norman RJ and Brännström M (1996) Cytokines in the ovary: pathophysiology and potential for pharmacological intervention Pharmacology and Therapeutics $69219-236$

Okada S, Hirohito K, George TJ, Gleich GJ and Leiferman KM (1997) Transmigration of eosinophils through basement membrane components in vitro: synergistic effects of platelet-activating factor and eosinophil-active cytokines American Journal of Respiratory Cell and Molecular Biology 16 $455-463$

Oskéritzian C, Milon G, Braquet P, Mencia-Huerta JM and David B (1996) Activated mast cells release biological activities able to support eosinophil production from mouse hemopoietic precursors Cellular Immunology 167 205-215

Pate JL (1995) Involvement of immune cells in regulation of ovarian function Journal of Reproduction and Fertility Supplement 49 365-377

Ricken AM, Spanel-Borowski K, Saxer M and Huber PR (1995) Cytokeratin expression in bovine corpora lutea Histochemistry 103 345-354

Spanel-Borowski K, Rahner P and Ricken AM (1997) Immunolocalization of CD18-positive cells in the bovine ovary Journal of Reproduction and Fertility 111 197-205

Standaert FE, Zamora CS and Chew BP (1991) Quantitative and qualitative changes in blood leukocytes in the porcine ovary American Journal of Reproductive Immunology 25 163-168

Vinatier D, Dufour P, Tordjeman-Rizzi N, Prolongeau JF, Depret-Moser S and Monnier JC (1995) Immunological aspects of ovarian function: role of the cytokines European Journal of Obstetrics, Gynecology and Reproductive Biology 63 155-168

Walsh GM (1997) Human eosinophils: their accumulation, activation and fate British Journal of Haematology 97 701-709

Walsh GM, Wardlaw AJ, Hartnell A, Sanderson CJ and Kay AB (1991) Interleukin- 5 enhances the in vitro adhesion of human eosinophils, but not neutrophils, in a leucocyte integrin (CD11/18)-dependent manner International Archives of Allergy and Applied Immunology 94 174-178

Wardlaw AJ, Walsh GM and Symon FA (1994) Mechanisms of eosinophil and basophil migration Allergy 49 797-807 